\title{
БУРЕНИЕ
}

УДК 622.58; https://doi.org/10.37878/2708-0080/2021-5.03

\section{ОСНОВНЫЕ НАПРАВЛЕНИЯ СОВЕРШЕНСТВОВАНИЯ АЛМАЗНЫХ БУРОВЫХ КОРОНОК}

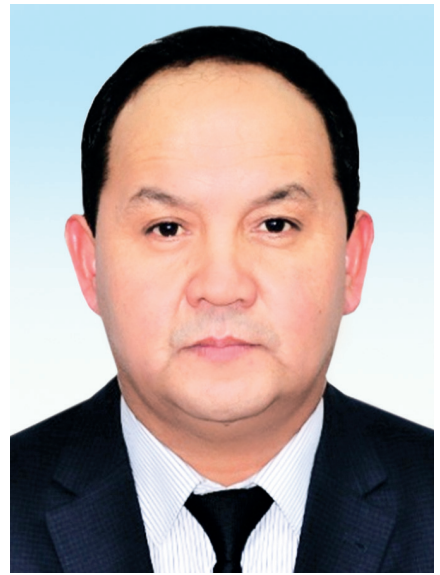

Б.T. PATOB ${ }^{\star 1,3}$, доктор технических наук, профрессор, https://orcid.org/0000-00034707-3322

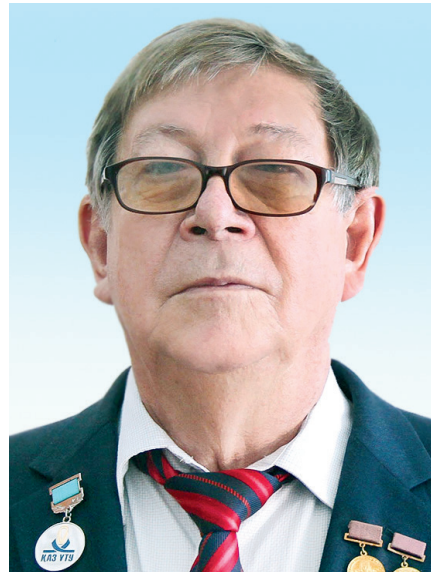

Б.В. ФЕДОРОВ ${ }^{1}$, доктор технических наук, главный научный сотрудник, https://orcid.org/0000-00021225-3203

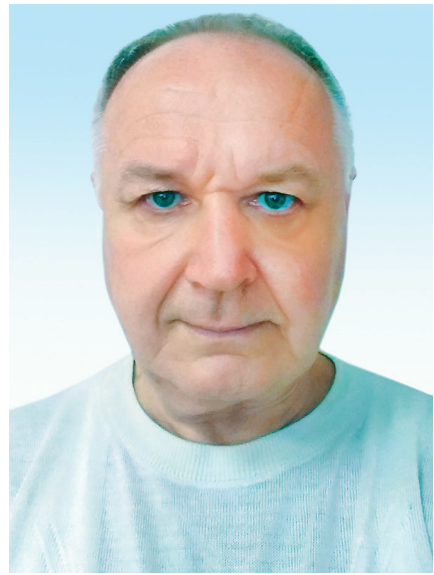

А.М. ИСОНКИН кандидат технических наук, https://orcid.org/0000-00023898-8806

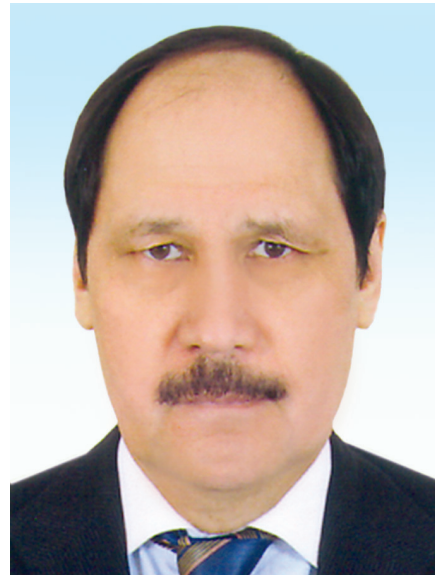

A.X. Сыздыков ${ }^{1}$, кандидат технических наук профресcop https://orcid.org/0000-0002 0182-4330

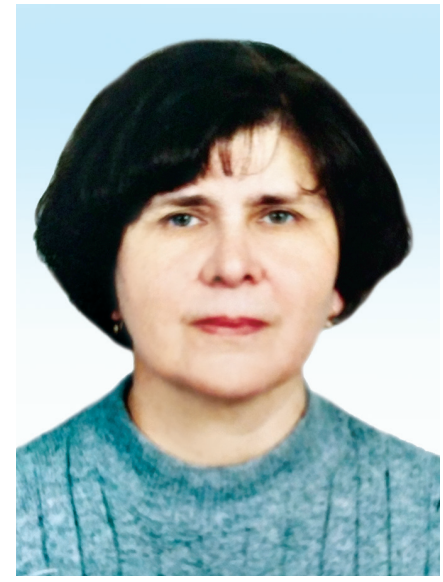

Г.Д. ИЛЬНИЦКАЯ², кандидат технических наук, https://orcid.org/0000-00015650-5612

\footnotetext{
* Адрес для переписки. E-mail: ratov69@mail.ru
} 
${ }^{1}$ НАО «КАЗАХСКИЙ НАЦИОНАЛЬНЫЙ ИССЛЕДОВАТЕЛЬСКИЙ

ТЕХНИЧЕСКИЙ УНИВЕРСИТЕТ ИМ. К.И. САТПАЕВА»,

Республика Казахстан, 050013, г. Алматы, ул. Сатпаева, 22

2 ИНСТИТУТ СВЕРХТВЕРДЫХ МАТЕРИАЛОВ ИМ. В.Н. БАКУЛЯ НАН УКРАИНЫ, Украина, 04074, г. Киев, ул. Автозаводская, 2

${ }^{3}$ КАСПИЙСКИЙ ОБЩЕСТВЕННЫЙ УНИВЕРСИТЕТ, Республика Казахстан, 050000, г. Алматы, пр. Сейфуллина, 521

Работа посвящена исследованиям, направленным на повышение стойкости и производительности алмазных буровых коронок при бурении твердых абразивных пород. Для достижения этой цели созданы многослойные коронки, в матрице которых размещены несколько алмазных импрегнированных слоев "гребешкового» профриля, представляющего круговые конусные выступы и впадины. Упомянутые импрегнированные слои по высоте чередуется с безалмазными слоями меньшей твердости и абразивности. Созданные на этом принципе казахстанские алмазные коронки под маркой КСБ прошли сравнительные испытания с коронками ведущих фрирм США, Канады, Китая, России при бурении самых твердых абразивных пород. Установлено, что лучшей коронкой по критерию эфффективности (отношение стоимости коронки к пробуренным ею метрам скважины) оказалась коронка КСБ.

С целью дальнейшего совершенствования алмазных инструментов разработана и запатентована алмазная коронка, у которой разновысотные импрегнированные слои гребешкового профиля размещены на многозаходной винтовой поверхности. Ожидается, что такая коронка позволит при бурении использовать существующий эфффект предварительного ослабления прочности породы, мощность которой в 5-10 раз превышает глубину внедрения алмазных зерен.

С использованием современных методов дополнительной сортировки и классифрикации получена партия высокопрочных термостойких алмазных шлифппорошков $c$ высокой их однородностью по прочности и линейным размерам. Исследовано влияние фризико-механических характеристик: прочности, термостойкости, однородности по прочности шлифрпорошков алмаза на износостойкость буровых коронок. Показано, что оснащение буровых коронок алмазами после их сортировки для повышения прочности, термостойкости и однородности по прочности и размерам зерен алмаза приводит к снижению интенсивности их изнашивания.

КЛЮЧЕВЫЕ СЛОВА: твердые абразивные породы, безалмазные слои, размещение слоев на винтовой поверхности, износостойкость, сортировка алмазов, синтетические алмазы, интенсивность изнашивания, прочность, термостойкость, однородность по прочности.

\section{АЛМАЗДЫ БҰРҒЫЛАУ КОРОНКАЛАРЫН ЖЕТІЛДІРУДІҢ НЕГІЗГІ БАҒЫТТАРЫ}

Б.Т. РАТОВ ${ }^{\star 1,3}$, техника ғылымдарының докторы, профеeccop, https://orcid.org/0000-0003-4707-3322 Б.В. ФЕДОРОВ 1 , техника ғылымдарының докторы, профресcop, https://orcid.org/0000-0002-1225-3203 А.М. ИСОНкИН ${ }^{2}$, техника ғылымдарының кандидаты, А.Ғ.Ж., https://orcid.org/0000-0002-3898-8806 А.Х. Сыздықов ${ }^{1}$, техника ғылымдарының кандидаты, https://orcid.org/0000-0002-0182-4330 Г.Д. ИЛЬНИЦКАЯ², техника ғылымдарының кандидаты А.Ғ.Ж., https://orcid.org/0000-0001-5650-5612

${ }^{1}$ Қ.И. САТПАЕВ АТЫНДАҒЫ ҚАЗАҚ ҰЛТТЫҚ ЗЕРТТЕУ ТЕХНИКАЛЫҚ УНИВЕРСИТЕТІ Қазақстан Республикасы, 050013, Алматы қ-сы. Сәтпаев к-сі, 22

²В. Н. БАКУЛЬ АТЫНДАҒЫ АСА ҚАТТЫ МАТЕРИАЛДАР ИНСТИТУТЫ, УКРАИНА ҰҒА, Украина, 04074 Киев қ., Автозаводская к-сі, 2

${ }^{3}$ КАСПИЙ ҚОҒАМДЫҚ УНИВЕРСИТЕТІ, Қазақстан Республикасы, 050000, Алматы, Сейфуллин д-ы, 521 
Жұмыс қатты абразивті жыныстарды бұрғылау кезінде алмазды бұрғылау коронкаларынің тұрақтылығы мен өнімділігін арттыруға бағытталған зерттеулерге арналған. Осы мақсатқа жету үшін көп қабатты коронкалар жасалды, олардың матрицасында дөңгелек конустық шығыңқы жерлер мен депрессияларды білдіретін "тарақ" профилінің бірнеше Алмаз сіңдірілген қабаттары орналасқан. Жоғарыда аталған имплантацияланған қабаттар төменгі қаттылық пен абразивтіліктің альмазсыз қабаттарымен ауысады. Осы қағидатта құрылған қазақстандық алмаз коронкалары КСБ маркасымен АҚШ, Канада, Қытай, Ресейдің жетекші фрирмаларының коронкаларымен ең қатты абразивті жыныстарды бұрғылау кезінде салыстырмалы сынақтардан өтті. Тиімділік критерийі бойынша ең жақсы тәж (тәж құнының ұңғыманың бұрғыланған метрлеріне қатынасы) КСБ тәжі екендігі анықталды.

Алмаз құралдарын одан әрі жетілдіру үшін алмаз тәжі жасалынған және патенттелген, онда тарақ профрилінің әртүрлі биіктіктері көп бұрандалы бетке орналастырылған. Мұндай тәж бұрғылау кезінде тау жыныстарының беріктігін алдын-ала әлсіретудің қолданыстағы әсерін қолдануға мүмкіндік береді деп күтілуде, оның қуаты алмаз дәндерін енгізу тереңдігінен 5-10 есе көп.

Қосымша сұрыптау мен жіктеудің заманауи әдістерін қолдана отырып, беріктізі мен сызықтық өлшемдері бойынша біркелкілігі жоғары беріктігі жоғары ыстыққа төзімді алмаз ұнтақтағыштарының партиясы алынды. Физикалық-механикалық сипаттамалардың әсері зерттелді: беріктік, ыстыққа төзімділік, алмаз тегістеу ұнтақтарының беріктіаі бойынша біркелкілігі бұрғылау коронкаларынің тозуға төзімділігіне. Алмаз дәндерінің беріктігі мен өлшемдері бойынша беріктігін, ыстыққа төзімділігін және біркелкілігін арттыру үшін сұрыпталғаннан кейін бұрғылау коронкаларын алмаздармен жабдықтау олардың тозу қарқындылығының төмендеуіне әкелетіні көрсетілген.

ТҮЙІн СөзДЕР: қатты абразивті тау жыныстар, алмазсыз қабаттар, қабаттарды бұрандалы бетке орналастыру, тозуға төзімділік, алмаз сұрыптау, синтетикалық алмаздар, тозу қарқындылығы, беріктігі, ыстыққа төзімділігі, беріктігі бойынша біркелкілігі.

\title{
MAIN DIRECTIONS FOR IMPROVING DIAMOND DRILL BITS
}

B. RATOV*1,3, Doctor of Technical Sciences, Professor, https://orcid.org/0000-0003-4707-3322

B. FEDOROV' ${ }^{1}$, Doctor of Technical Sciences, Professor, https://orcid.org/0000-0002-1225-3203

A. ISONKIN², Candidate of Technical Sciences, SR, https://orcid.org/0000-0002-3898-8806

A. SYZDYKOV 1 , Candidate of Technical Sciences, https://orcid.org/0000-0002-0182-4330

G. ILNITSKAYA², Candidate of Technical Sciences, SR, https://orcid.org/0000-0001-5650-5612

1SATPAYEV KAZAKH NATIONAL RESEARCH TECHNICAL UNIVERSITY

22, Satpayev st., Almaty, 050013, Republic of Kazakhstan

\author{
${ }^{2}$ V.N. BAKUL INSTITUTE FOR SUPERHARD MATERIALS \\ OF THE NAS OF UKRAINE, \\ 2, Avtozavodskaya st., Kiev, 04074, Ukraine \\ ${ }^{3}$ CASPIAN PUBLIC UNIVERSITY, \\ 521, Seifullin Ave, 050000, Almaty, Republic of Kazakhstan
}

The work is devoted to research aimed at increasing the durability and productivity of diamond drill bits when drilling hard abrasive rocks. To achieve this goal, multilayer crowns have been created, in the matrix of which several diamond impregnated layers of a "comb" profile are placed, representing circular conical protrusions and depressions. The above-mentioned impregnated layers alternate in height with non-diamond layers of lower hardness and abrasiveness. Kazakhstani diamond bits created on this principle under the KSB brand have passed comparative tests with the bits of the leading companies in the USA, Canada, China, and Russia when drilling the hardest abrasive rocks. It was found that the best bit in terms of the efficiency criterion (the ratio of the cost of the bit to the meters drilled by it) was the KSB bit. 
To further improve diamond tools, a diamond crown was developed and patented, in which impregnated layers of comb profile of different heights are placed on a multi-start helical surface. It is expected that such a bit will allow drilling to use the existing effect of preliminary weakening of the rock strength, the thickness of which is 5-10 times greater than the penetration depth of diamond grains.

Using modern methods of additional sorting and classification, a batch of high-strength heatresistant diamond grinding powders with high uniformity in strength and linear dimensions was obtained. The influence of physical and mechanical characteristics: strength, heat resistance, uniformity in strength of diamond grinding powders on the wear resistance of drill bits has been investigated. It is shown that equipping drill bits with diamonds after their sorting to increase strength, heat resistance and uniformity in strength and size of diamond grains leads to a decrease in the intensity of their wear.

KEY WORDS: hard abrasive rocks, non-diamond layers, placement of layers on a helical surface, wear resistance, sorting of diamonds, synthetic diamonds, wear rate, strength, heat resistance, uniformity in strength. звестно, что алмазные буровые коронки широко применяются для бурения пород средней твердости и твердых, причем с повышением глубины скважины эффективность упомянутых породоразрушающих инструментов возрастает. Причина этого заключается в высокой стойкости алмазных буровых коронок в сравнении с другими инструментами. Особенно отчетливо проявляется это свойство при оснащении алмазными коронками снарядов со съемными керноприемниками (ССК) [1]. Вместе с тем, имеются ряд проблем, решение которых позволит значительно повысить технико-экономические показатели бурения алмазными коронками. К таким, не до конца решенным проблемам, относятся:

- недостаточная стойкость и производительность алмазного инструмента при бурении твердых абразивных пород;

- неполное использование особенностей физических явлений при внедрении алмазных зерен в горную породу, которые следует учитывать при создании инструментов для повышения эффективности разрушения забоя скважины;

- недостаточное использование методов и средств повышения качества алмазного сырья для изготовления буровых коронок; И, конечно, важным моментом является строгое соблюдение технологии изготовления алмазных инструментов.

Определенные шаги в решении упомянутых проблем уже сделаны. Для повышения стойкости алмазных инструментов создана и испытана в производственных условиях буровая коронка (рисунок 1) с несколькими алмазосодержащими импрегнированными слоями, размещенными по высоте матрицы [1,2].

Форма алмазных импрегнированных слоев представляет «гребешковый» профиль, т.е. круговые конусные выступы и впадины. Между упомянутыми слоями размещены безалмазные слои меньшей твердости, выполненные, например, из твердого сплава ВК-15 или ВК-20.

На рисунке 2 изображен один конусный выступ импрегнированного слоя «гребешковой» формы и усилия, действующее на него: сила Р0, представляющая долю от общей нагрузки на коронку, на единицу длины выступа, и реакции № со стороны разрушаемой породы.

Достоинством рассмотренной алмазной коронки является повышение ее работоспособности (стойкости). Последнее объясняется тем, что по мере износа первого 


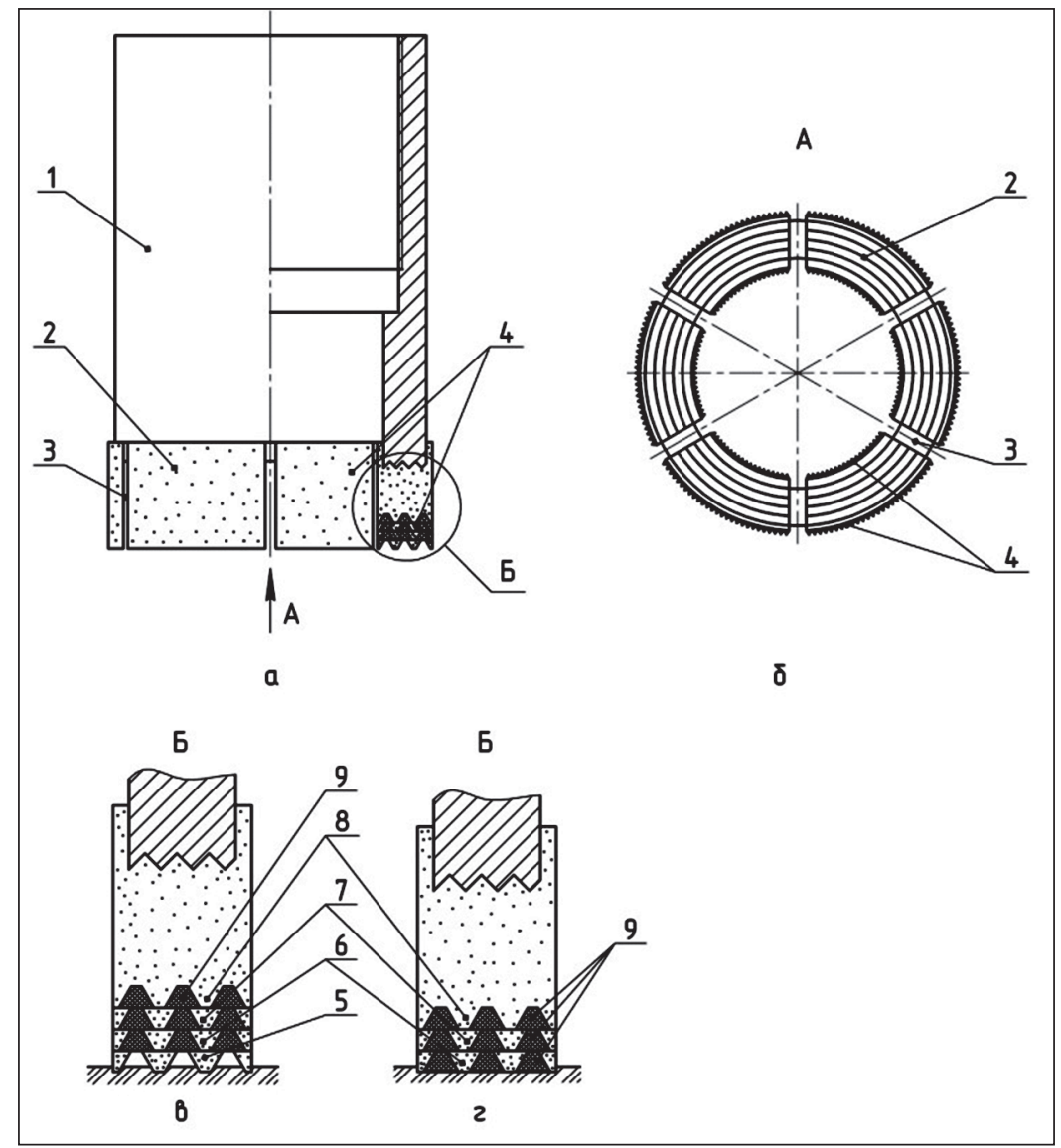

Рисунок 1 - Многослойная алмазная коронка с «гребешковым» профилем алмазосодержащих импрегнированных слоев. (патент РК №13581):

а - вид со стороны корпуса; б - вид А коронки с торца; в - продольный разрез алмазонесущей матрицы в увеличенном масштабе (узел Б на рисунке а); г - продольный разрез матрицы после износа первого алмазного слоя. 1 - корпус; 2 - матрица; 3 - промывочные каналы; 4 - подрезные алмазы; 5,6,7,8 - алмазосодержащие слои; 9 - безалмазные слои

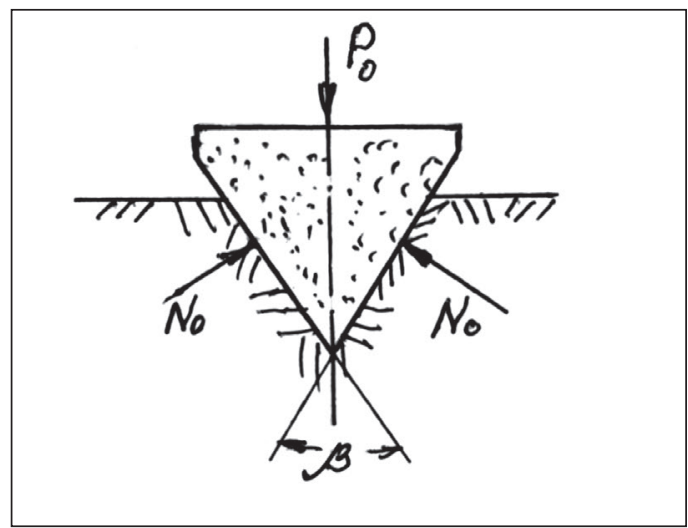

Рисунок 2 - Продольный разрез конусного выступа алмазного импрегнированного слоя и усилия, приложенные к нему 
алмазного импрегнированного слоя обнажение второго происходит за счет быстрого износа безалмазного слоя, затем по той же схеме происходит обнажение третьего импрегнированного слоя и т.д., до полного износа матрицы коронки.

Вторым достоинством коронки (рисунок 1) является выполнение всех алмазосодержащих слоев по «гребешковому» профилю. Действительно, как следует из

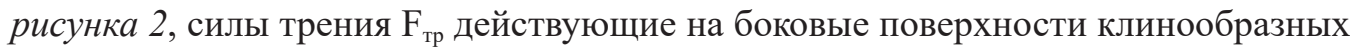
выступов, равны:

$$
\mathrm{F}_{\text {тр } 0}=2 \mathrm{~N}_{0} \mathrm{f}=\mathrm{P}_{0} \mathrm{f} / \sin \beta / 2 \text {, }
$$

где $\mathrm{N}_{0}$ - реакция породы на внедряемый алмазный выступ, $\mathrm{f}$ - коэффициент трения на контакте «алмазный выступ-порода»; $\beta$ - угол приострения клинообразного выступа.

Как известно, твердые горные породы при воздействии алмазных импрегнированных конусных выступов разрушаются в режиме трения и микрорезания. Из формулы (1) следует, что сила $\mathrm{F}_{\text {тр } 0}$ возрастает с уменьшением угла приострения $\beta$ и при увеличении $\mathrm{P}_{0}$ и $\mathrm{N}_{0}$.

«Гребешковый» профиль алмазосодержащих слоев оказывает также расклинивающие действие выступов на породу забоя, что приводит к интенсификации разрушения последнего. Это положение подтверждено экспериментально [3]. В частности, в упомянутой работе показано, что при бурении гранита X категории с уменьшением угла приострения кольцевых конусных выступов с $90^{\circ}$ до $30^{\circ}$ механическая скорость бурения возрастает более чем в 2 раза.

Созданная многослойная коронка (рисунок 1) под маркой КСБ-2 использована, наряду с другими алмазными коронками, для бурения колонковых скважин комплексами ССК нижней части геологического разреза Чиганак-Улькенсайского рудного поля [3]. В упомянутом разрезе залегают твердые абразивные породы X-XII категорий по буримости: кремнисто-баритовая брекчия, кремнистые породы, яшмоиды с баритом, массивные кремни. Бурение осуществляли коронками типа NQ следующих производителей: Damatec (США), ALFA-08 (Канада), Ultra Terra (Канада), Boart Longyear (Канада), Терек Алмаз (Россия), Bolwa (Китай). Все перечисленные коронки были импрегнированными.

Параметры технологического режима бурения следующие: осевая нагрузка на коронку $-(2 \div 2,2)$ кН; частота вращения коронки - $(640 \div 700)$ мин $^{-1}$; расход промывочного бурового раствора $-(25 \div 40)$ дм³ $^{3}$ мин.

Результаты сравнительных испытаний и их статистической обработки приведены в таблице 1. Величина полученных значений среднеквадратических отклонений $\delta$ и коэффициентов вариации $\mathrm{V}$ свидетельствует о достоверности полученных результатов [4]. т.е. соотношение (2) связывает стоимость коронки с ее стойкостью S (средней проходкой). Отсюда следует, что чем меньше F, тем большую эффективность показывает буровая коронка. В столбце 7 приведены расчетные значения критерия F для испытываемых коронок. Из приведенных данных видно, что наибольшую эффективность показала коронка КСБ, у которой величина $\mathrm{F}$ минимальна $(\mathrm{F}=6,87)$, затем следует коронка фирмы Терек-Алмаз, у которой $\mathrm{F}=9,62$, коронки у других производителей показали величину F более 10. 
Таблица 1 - Результаты сравнительных испытаний импрегнированных алмазных коронок NQ (76 мм)

\begin{tabular}{|c|c|c|c|c|c|c|}
\hline $\begin{array}{c}\text { Производитель } \\
\text { коронок }\end{array}$ & $\begin{array}{c}\text { Проходка } \\
\text { общая } \\
\text { коронкой м }\end{array}$ & $\begin{array}{c}\text { Средняя } \\
\text { проходка } \\
\text { на коронку } \\
\text { (стойкость) } \\
\text { S, м }\end{array}$ & $\begin{array}{c}\text { Средне } \\
\text { квадратическое } \\
\text { отклонение } \delta, \text { м }\end{array}$ & $\begin{array}{c}\text { Коэффициент } \\
\text { вариации } \\
\text { V=S/S' }\end{array}$ & $\begin{array}{c}\text { Стоимость } \\
\text { коронки C, } \\
\text { доллар }\end{array}$ & $\begin{array}{c}\text { Критерий } \\
\text { эффективности } \\
\text { F=C/S }\end{array}$ \\
\hline 1 & 2 & 3 & 4 & 5 & 6 & 7 \\
\hline $\begin{array}{l}\text { Damatec } \\
\text { (США) }\end{array}$ & 560 & 40 & 1,3 & 0,032 & 467 & 11,675 \\
\hline $\begin{array}{l}\text { ALFA-08 } \\
\text { (Канада) }\end{array}$ & 170 & 30 & 1,35 & 0,045 & 533 & 17,77 \\
\hline $\begin{array}{l}\text { Ultra Ferra } \\
\text { (Канада) }\end{array}$ & 175 & 35 & 1,38 & 0,039 & 567 & 16,2 \\
\hline $\begin{array}{l}\text { Bear Longyear } \\
\text { (Канада) }\end{array}$ & 355 & 50 & 1,42 & 0,028 & 600 & 12 \\
\hline $\begin{array}{c}\text { Терек Алмаз } \\
\text { (Россия) }\end{array}$ & 315 & 45 & 1,45 & 0,032 & 433 & 9,62 \\
\hline $\begin{array}{c}\text { Bolwa } \\
\text { (Канада) }\end{array}$ & 150 & 30 & 1,33 & 0,044 & 333 & 11,1 \\
\hline КСБ-2 & 630 & 63 & 1,45 & 0,023 & 433 & 6,87 \\
\hline
\end{tabular}

За критерий эффективности F принята стоимость С буровых коронок, отнесенная к 1 м проходки скважины упомянутыми коронками:

$$
\mathrm{F}=\mathrm{C} / \mathrm{S}
$$

Исследования по второму направлению опираются на результаты работ бывшего ВИТРа (Санкт-Петербург, Россия), посвященные изучению физических эффектов, возникающих при внедрении алмаза в твердые породы [5]. Установлено, что при внедрении алмазного зерна (или клинообразного импрегнированного слоя) в породе формируется зона внедрения $\mathrm{h}_{\mathrm{B}}$ и зона разрушения породы $\mathrm{h}_{\mathrm{p}}$, причем последняя превышает $\mathrm{h}_{\text {в }}$ в $5-10$ раз, т.е. $\mathrm{h}_{\mathrm{p}}=(5 \div 10) \mathrm{h}_{\mathrm{s}}$. Поэтому родилась идея - использовать эффект образования разрушенной разбитой трещинами породы, размещенной ниже зоны внедрения, для интенсификации процесса углубления забоя скважины.

С этой целью разработана многослойная импрегнированная коронка (рисунок 3), матрица которой содержит по высоте несколько алмазосодержащих слоев 5 «гребешкового» профиля, размещенных равномерно на трехзаходной винтовой поверхности [6]. Импрегнированные алмазные слои 5 разделяются безалмазными слоями 6 меньшей твердости, а шаг трехзаходной винтовой поверхности определяется глубиной разрушения породы $\mathrm{h}_{\mathrm{p}}$.

Работа коронки осуществляется следующим образом. В начальный момент процесса бурения после подачи промывочной жидкости, приложения осевой нагрузки и крутящего момента коронка внедряется в породу концами граней секторов, 
наибольших по высоте. При этом образующаяся конусная кольцевая форма профиля алмазосодержащего слоя облегчает разрушение забоя скважины, так как обеспечивает большую площадь контакта алмазных зерен с горной породой и высокие удельные нагрузки на последнюю.

Каждый из указанных секторов коронки, воздействуя на породу наибольшими по высоте конусными кольцевыми выступами алмазосодержащего слоя, пройдя 1/3 окружности забоя, формирует аналогичные по форме конусные кольцевые впадины, а под ними - зону разрушения, т.е. зону раздробленной трещинами, но не удаленной породы (рисунок 3 в, г).

При дальнейшем вращении коронки каждая группа секторов, расположенная на одном заходе винтовой поверхности, перемещается в часть забоя, подготовленного к углублению впереди работающей группой секторов, расположенных на соседнем заходе. Таким образом, через 1/3 оборота вследствие сформированной на забое

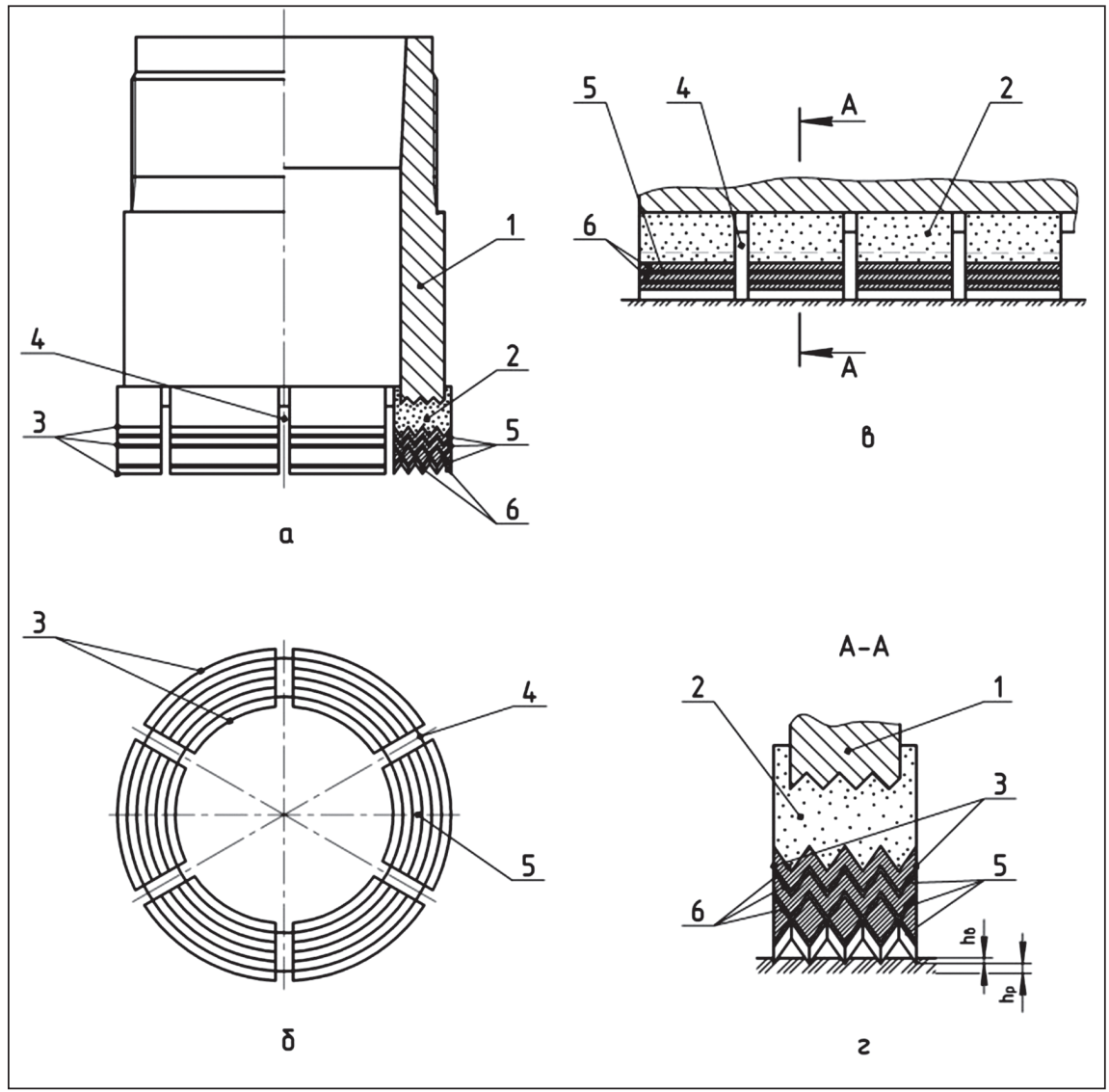

Рисунок 3 - Многослойная алмазная коронка алмазосодержащие импрегнированные слои, которой имеют «гребешковый профиль и размещены равномерно на трехзаходной винтовой поверхности (патент РК №25764):

а - вид со стороны корпуса; б - вид с торца; в - развертка матрицы коронки по среднему диаметру; г - разрез матрицы по А-А; 1 - корпус; 2 - матрица; 3 - подрезные алмазы; 4 - промывочные каналы; 5 - алмазосодержащие импрегнированные слои; 6 - безалмазные слои 
кольцевой зоны разрушения и действия постоянной осевой нагрузки секторы матрицы, вытесняя раздробленную породу, перемещаются вниз на величину, близкую к толщине разрушенного слоя, и осуществляют послойное удаление последнего. Формирующиеся на забое кольцевые выступы разрушаются под действием всегда имеющихся вибраций буровой коронки. После отработки первого, начиная от забоя алмазосодержащего слоя, вследствие опережающего износа безалмазного слоя происходит обнажение второго алмазосодержащего слоя секторов, который осуществляет дальнейшее углубление забоя. Опережающий износ безалмазного слоя меньшей твердости позволяет, постепенно обнажая алмазосодержащий слой, полностью отработать его при разрушении породы. Далее процесс углубления забоя повторяется до полной отработки всех алмазосодержащих слоев матрицы.

Наклонное (по отношению к забою) положение алмазосодержащих слоев, расположенных на винтовой поверхности и разделяющие их безалмазные слои, а также их конусная кольцевая форма позволяет создавать большие удельные нагрузки на забой, реализовать эффект самозатачивания и особенности механизма разрушения твердых пород при воздействии алмазных зерен. Таким образом, использование предлагаемой алмазной коронки позволяет увеличить ее удельное контактное давление на породу, скорость разрушения забоя, стойкость инструмента, что повышает в целом эффективность проходки скважины.

В настоящее время осуществляются подготовительные работы по созданию опытной партии коронок по патенту РК №25764 для проверки их эффективности в лабораторных и производственных условиях.

По мере повышения требований к износостойкости породоразрушающего инструмента возрастают требования к качеству используемых для его оснащения синтетических алмазных шлифпорошков.

В свою очередь, свойства алмазных шлифпорошков обусловливаются технологиями синтеза, извлечения, обработки, классификации по размерам и форме, сортировки по физико-химическим свойствам, обеспечивающими получение шлифпорошков с заданными свойствами. Исходя из требований, предъявляемых к буровому инструменту, основными характеристиками качества алмазного шлифпорошка являются крупность в виде зернистости и зернового состава, прочностные характеристики: прочность, термостабильность и однородность шлифпорошка по прочностным и геометрическим характеристикам в виде линейных размеров зерен алмаза.

Однородность является важной характеристикой качества порошков сверхтвердых материалов, позволяющей объективно отражать состояние их качества. В настоящее время наблюдается тенденция повышения интереса к однородности порошков по различным технологическим характеристикам.

В решении проблемы повышения качества алмазного сырья для изготовления буровых коронок значительных успехов достиг Институт сверхтвердых материалов им. В.Н. Бакуля (ИСМ, НАН, Украина).

С целью получения высокопрочных алмазных шлифпорошков марок АC160 - АC400 был разработан ряд методов [7], позволяющих оценивать однородность шлифпорошков алмазов по основным технологическим характеристикам качества и, прежде всего, по прочностным и геометрическим характеристикам их зерен. 
Одним из важнейших условий обеспечения высокой износостойкости породоразрушающего инструмента является повышение однородности указанных шлифпорошков по зерновому составу и прочности.

При этом использование синтетических алмазов более прочных марок способствует увеличению их выступания из матрицы и зазора между ней и горной породой. Как следствие, это приводит к снижению вероятности расклинивания частиц шлама между рабочим торцом коронки и забоем скважины, уменьшению степени их активного воздействия на матрицу. В совокупности это уменьшает затраты энергии на трение и разрушение горной породы и снижает интенсивность изнашивания инструмента [8].

Для исследования по установлению влияния прочностных показателей синтетических алмазов на механическую скорость бурения и износостойкость буровых коронок конструкции ИСМ НАН Украины шлифпорошки алмазов АСТ200 зернистостью 355/300 мкм с помощью адгезионно-магнитной сортировки разделили по дефектности поверхности на шесть продуктов. Согласно методам, изложенным в [9], определяли физико-механические характеристики полученных шлифпорошков, в частности статическую прочность $P$. Дефектность поверхности зерен оценивали по коэффициенту поверхностной активности $\mathrm{K}_{\mathrm{a}}$. Содержание объемных дефектов в зернах алмаза определяли по измеряемой удельной магнитной восприимчивости порошков $\chi$. Термостабильность шлифпорошков оценивали по коэффициенту термостабильности $\mathrm{K}_{\text {тс }}$ К Кроме того, определяли состав шлифпорошков по прочности и рассчитывали коэффициенты однородности по прочности К одн. пр.

Износостойкость буровых коронок исследовали в соответствии с методикой, изложенной в работе [10], бурением гранита X категории буримости Коростышевского месторождения при фиксированном углублении коронки 60 мкм за оборот, осевой нагрузке 400-800 даН и скорости вращения 600-1500 мин ${ }^{-1}$ с использованием специально оборудованного бурового стенда, оснащенного измерительной аппаратурой.

В результате использования сортировки синтетических алмазов были получены отдельные партии шлифпорошков алмазов, характеристики которых представлены в таблице 2.

Используя алмазы с разными прочностными характеристиками, изготовили 6 групп опытных коронок типа БС-06 диаметром 76 мм.

Эксплуатационные характеристики бурового инструмента оценивали по интенсивности изнашивания его породоразрушающих элементов $(I, \mathrm{Mm} / \mathrm{M})$ как отношению линейного износа по высоте к проходке на коронку и по удельной работе разрушения

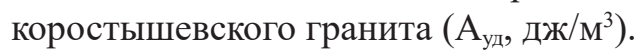

Результаты лабораторных исследований бурения гранита импрегнированными коронками, изготовленными из различных по прочности и зернистости шлифпорошков, полученных после сортировки алмазов, приведены в таблице 3.

Анализ данных, приведенных в таблице 2, показал, что с повышением прочности шлифпорошков алмаза удельная работа разрушения породы $\left(\mathrm{A}_{\text {об }}\right)$ снижается, что свидетельствует о более эффективном разрушении породы таким инструментом. При этом снижается усилие резания породы $\left(\mathrm{P}_{z}\right)$, что свидетельствует о том, что при использовании высокопрочных алмазов снижается вероятность скола их вершин, разрушающих горную породу. 


\section{БУРЕНИЕ}

Таблица 2 - Результаты адгезионно-магнитной сортировки исходной партии алмазов АСТ200 зернистостью $355 / 300$

\begin{tabular}{|c|c|c|c|c|c|c|c|c|}
\hline \multirow{2}{*}{$\begin{array}{c}\text { Продукт } \\
\text { разделения }\end{array}$} & \multirow{2}{*}{$\begin{array}{c}\text { Выход, } \\
\%\end{array}$} & \multicolumn{7}{|c|}{ Характеристики шлифпорошков алмаза } \\
\hline & & $\chi_{\mathbf{m}^{3} / \mathbf{k r}}^{10^{-8}}$ & $\begin{array}{l}K_{a}, \\
\%\end{array}$ & $\begin{array}{l}\mathbf{P}, \\
\mathbf{H}\end{array}$ & $\begin{array}{c}P_{\text {Tor }} \\
H\end{array}$ & $\begin{array}{c}\mathbf{K}_{\text {одн. пр. }} \\
\%\end{array}$ & $K_{r c}$ & Марка \\
\hline 1 & 2,0 & 1,6 & 0,04 & 349,4 & 335,4 & 82 & 0,96 & ACT250 \\
\hline 2 & 11,2 & 3,5 & 0,10 & 336,1 & 319,3 & 74 & 0,95 & ACT250 \\
\hline 3 & 30,6 & 4,9 & 0,14 & 312,4 & 281,2 & 58 & 0,90 & АCT200 \\
\hline 4 & 33,5 & 6,6 & 0,16 & 288,4 & 248,0 & 56 & 0,86 & ACT200 \\
\hline 5 & 10,7 & 7,2 & 0,20 & 276,0 & 234,6 & 52 & 0,85 & АCT200 \\
\hline 6 & 12,0 & 7,9 & 0,25 & 259,0 & 204,6 & 40 & 0,79 & ACT200 \\
\hline Исходный & 100 & 7,6 & - & 291,1 & 244,5 & 18 & 0,84 & АCT200 \\
\hline
\end{tabular}

Таблица 3 - Результаты лабораторных испытаний буровых коронок, оснащенных алмазами зернистостью 355/300, при углублении в породу 60 мкм/об

\begin{tabular}{|c|c|c|c|c|c|c|}
\hline \multicolumn{3}{|c|}{$\begin{array}{c}\text { Технологические характеристики } \\
\text { алмазов }\end{array}$} & \multicolumn{4}{|c|}{$\begin{array}{c}\text { Эксплуатационные характеристики } \\
\text { коронок }\end{array}$} \\
\hline Марка & $P, \mathrm{H}$ & $\mathbf{K}_{\text {одн пр, }} \%$ & $\begin{array}{c}\text { Скорость } \\
\text { вращения, } \\
\text { мин }^{-1}\end{array}$ & 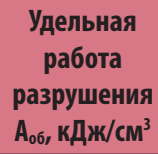 & $\begin{array}{c}\text { Усилие } \\
\text { резания, } \\
\text { P }_{z}, \mathrm{H}\end{array}$ & $\begin{array}{c}\text { Интенсивность } \\
\text { изнашивания I, } \\
\text { мм/м·10-2 }\end{array}$ \\
\hline AC200 & 259,0 & 40 & \multirow{7}{*}{750} & 4,07 & 2270 & 9,14 \\
\hline AC200 & 276,0 & 52 & & 3,89 & 2172 & 8,39 \\
\hline $\begin{array}{l}\text { AC200 } \\
\text { исX. }\end{array}$ & 291,1 & 18 & & 3,03 & 1685 & 7,42 \\
\hline AC200 & 288,4 & 56 & & 3,68 & 2057 & 7,88 \\
\hline AC200 & 312,4 & 58 & & 2,74 & 1526 & 6,87 \\
\hline AC250 & 336,1 & 74 & & 2,51 & 1405 & 6,02 \\
\hline AC250 & 349,4 & 82 & & 2,12 & 1186 & 5,04 \\
\hline AC200 & 259,0 & 40 & \multirow{7}{*}{1180} & 2,93 & 1615 & 12,76 \\
\hline AC200 & 276,0 & 52 & & 2,84 & 1564 & 11,38 \\
\hline $\begin{array}{l}\text { AC200 } \\
\text { исX. }\end{array}$ & 291,1 & 18 & & 2,18 & 1221 & 10,2 \\
\hline AC200 & 288,4 & 56 & & 2,65 & 1490 & 10,8 \\
\hline AC200 & 312,4 & 58 & & 1,98 & 1205 & 9,45 \\
\hline AC200 & 336,1 & 74 & & 1,81 & 1016 & 8,87 \\
\hline AC250 & 349,4 & 82 & & 1,52 & 859 & 7,39 \\
\hline
\end{tabular}


Подтверждением этого могут быть данные по распределению высоты выступания алмазов на рабочем торце коронок, приведенные на рисунке 4.

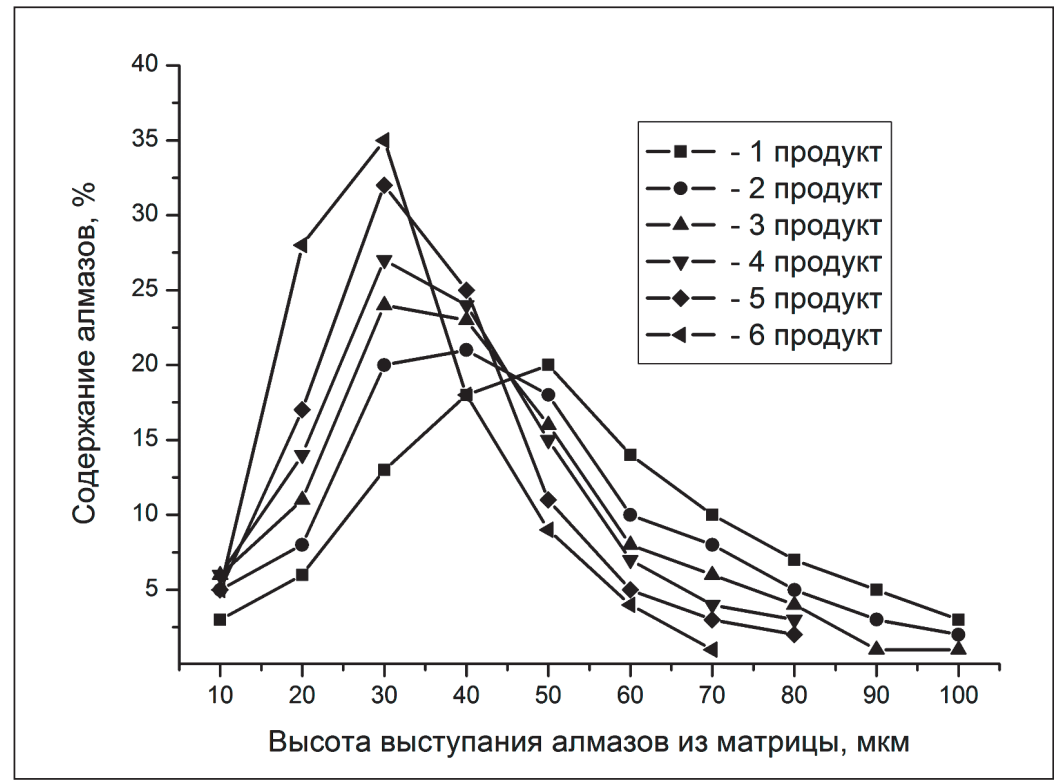

Рисунок 4 - Распределение алмазов по высоте выступания из матрицы в зависимости от их качественных показателей

Следует отметить, что повышение прочности алмазов, использованных для оснащения опытных коронок, в 1,35 раза приводит к снижению интенсивности изнашивания инструмента в $1,73-1,81$ раза.

Для алмазов с низкой дефектностью поверхности, более высокой однородностью и прочностью (продукты 1 - 3) характерно большее в процентном соотношении количество зерен, имеющих высоту выступания в диапазоне 50 - 100 мкм. Снижение качественных показателей алмазов приводит к уменьшению высоты их выступания из матрицы коронки, связанному со скалыванием вершин зерен, контактирующих с горной породой.

Сравнительный анализ полученных результатов свидетельствуют о явной перспективности оснащения буровых коронок синтетическими алмазами с низкой дефектностью поверхности, более высокой прочностью и однородностью по прочности.

\section{Выводы}

1. Для повышения производительности бурения в твердых абразивных породах рекомендуется применять алмазные коронки с многослойным размещением импрегнированных слоев «гребешков» профиля, представляющим концентрические круговые конусы и впадины, причем упомянутые слои разделяются безалмазными слоями меньшей твердости. Угол приострения импрегнированных круговых конусов рекомендуется делать возможно меньше, однако на практике с учетом прочности упомянутых конусов, он составляет $45-55^{\circ}$.

2. Следует изготовить опытную партию многослойных коронок, матрица которых содержит разновысотные импрегнированные слои, размещенные на трехзаходной 
винтовой поверхности. Провести опытные испытания упомянутых коронок с целью обнаружения эффекта вовлечения в процесс бурения ослабленную трещинами горную породу, залегающую ниже глубины внедрения алмазных зерен коронки.

3. Современные методы дополнительной сортировки и классификации позволяют получить высокопрочные термостойкие алмазные шлифпорошки с высокой их однородностью по прочности и линейным размерам.

4. Оснащение буровых коронок термостойкими алмазами после их сортировки для повышение прочности и однородности по прочности и размерам зерен алмаза способствует снижению вероятности разрушения их вершин, активно разрушающих горную породу, увеличению их высоты выступания из матрицы, и приводит к снижению интенсивности изнашивания инструмента в $1,73-1,81$ раза.

«Данное исследование финансировалось Комитетом науки Министерства образования и науки Республики Казахстан (грант № АР08857201)».

"This research has wais funded by the Science Committee of the Ministry of Education and Science of the Republic of Kazakhstan (Grant No. APAP08857201)».

\section{ЛИТЕРАТУРА}

1 Кудайкулов С.К. Бурение скважин в сложных условиях снарядами со съемными керноприемниками. - Алматы: Изд.центр КазНИТУ, 2010, 345c. [Kudaykulov S.K. Bureniye skvazhin v slozhnykh usloviyakh snaryadami so s"yomnymi kernopriyemnikami. - Almaty: Izd.tsentr KazNITU, 2010, 345 s.].

2 Предварительный патент №13581 РК. Алмазная буровая коронка / Кудайкулов С.К., Федоров Б.В. и др. Опубл. 15.10.2003 г. Бюл. №10. [Predvaritel'nyy patent №13581S RK. Almaznaya burovaya koronka / Kudaykulov C.K., Fedorov B.V. i dr. Opubl. 15.10.2003 g. Byulleten' №10.].

3 Федоров Б.В., Кудайкулова Г.А., Бердибаев И.М.. Результаты сравнительных испытаний алмазных буровых коронок ведущих фирм // Вестник КазНТУ. - 2014. -№2(102). C. 76-79. [Fedorov B.V., Kudaykulova G.A., Berdibayev I.M. Rezul'taty ispytaniy almaznykh burovykh koronok vedushchikh firm // Vestnik KazNTU. - 2014. - №2 (102). - S 76-79].

4 Танатаров Т.Т., Билецкий М.Т. Основы научных исследований и оптимизации в бурении. - Алматы: РИК, 1998. - 220 с. [Tanatarov Т.T., Biletskiy M.T.. Osnovy nauchnykh issledovaniy i optimizatsii v burenii. - Almaty: RIK, 1998. - 220 s.].

5 Травкин В.С., Берестенев Л.К. и др. Породоразрущающий инструмент для геологоразведочных скважин. Справочник. - М.: Недра, 1979. - 359 с. [Travkin V.S., Berestenev i dr. Porodorazrushchayushchiy instrument dlya geologorazvedochnykh skvazhin L.K.. Spravochnik. - M.: Nedra, 1979. - 359 s.].

6 Инновационный патент №25764 РК. Алмазная буровая коронка / Федоров Б.В., Кудайкулова Г.А. и др. Опубл. 2012 г. Бюл. №5. [Innovatsionnyy patent №25764 RK. Fedorov B.V., Kudaykulova G.A. i dr. Almaznaya burovaya koronka. Opubl. 2012 g. Byulleten' №5].

7 Новиков Н. В., Невструев Г. Ф., Ильницкая Г. Д. и др. Оценка качества порошков сверхтвердых материалов. Часть 1. Теоретические основы метода оценки характеристик качества // Сверхтвердые материалы. - 2006. - № 5. - С. 74-83. Ч. 2. Практическое применение нового метода оценки характеристик качества // Сверхтвердые матер. - 2006. - № 6. - C. 58-67. [Novikov N. V., Nevstruyev G. F., Il'nitskaya G. D. i dr. 
Otsenka kachestva poroshkov sverkhtverdykh materialov. Chast' 1. Teoreticheskiye osnovy metoda otsenki kharakteristik kachestva // Sverkhtverdyye materialov. -2006. - № 5. - S. 74-83. Ch. 2. Prakticheskoye primeneniye metoda otsenki kachestva // Sverkhtverdyye mater. - 2006. - № 6. - S. 58-67.].

8 Соловьев Н.В., Башкатов Д.Н., Горшков Л.К. и др. Геологоразведочный породоразрушающий инструмент на основе алмазов и сверхтвердых материалов - Новочеркасск: ЮРГТУ (НПИ), 2009. -334 с. [Solov'yev N.V., Bashkatov D.N., Gorshkov L.K. i dr. Geologorazvedochnyy porodorazrushayushchiy instrument na osnove almazov i sverkhtverdykh materialov . - Novocherkassk: YURGTU (NPI), 2009. - 334 s.].

9 Новиков Н. В., Невструев Г. Ф., Ильницкая Г. Д. и др. Оценка качества порошков сверхтвердых материалов. Часть 1. Теоретические основы метода оценки характеристик качества // Сверхтвердые материалы. - 2006. - № 5. - С. 74-83. Ч. 2. Практическое применение нового метода оценки характеристик качества // Сверхтвердые матер. - 2006. - № 6. - C. 58-67. [Novikov N. V., Nevstruyev G. F., Il'nitskaya G. D. i dr. Otsenka kachestva poroshkov sverkhtverdykh materialov. Chast' 1. Teoreticheskiye osnovy metoda otsenki kharakteristik kachestva // Sverkhtverdyye mater. - 2006. - № 5. - S. 74-83. CH. 2. Prakticheskoye primeneniye novogo metoda otsenki kharakteristik kachestva // Sverkhtverdyye mater. - 2006. - № 6. - S. 58-67.].

10 Бакуля В.Н. Синтетические алмазы в геологоразведочном бурении. - Киев.: Наукова думка, 1978. - 232 с. [Bakulya V.N. Sinteticheskiye almazy v geologorazvedochnom burenii. - Kiev: Naukova dumka, 1978. - 232 s.]. 